\title{
Intrinsic current generated, omnidirectional phase precession and grid field scaling in toroidal attractor model of medial entorhinal path integration
}

\author{
Zaneta Navratilova*, Jean-Marc Fellous and Bruce L McNaughton
}

Address: ARL Neural Systems, Memory and Aging, University of Arizona, Tucson, Arizona 85724, USA

Email: Zaneta Navratilova* - zanetan@email.arizona.edu

* Corresponding author

from Seventeenth Annual Computational Neuroscience Meeting: CNS*2008

Portland, OR, USA. 19-24 July 2008

Published: II July 2008

BMC Neuroscience 2008, 9(SuppI I):P2I doi:I0.I I86/I47I-2202-9-SI-P2I

This abstract is available from: http://www.biomedcentral.com/I47I-2202/9/SI/P2 I

(c) 2008 Navratilova et al; licensee BioMed Central Ltd.

Understanding of how hippocampal circuits accomplish path integration was advanced with the discovery of 'grid cells' in medial entorhinal cortex (MEC) [1]. Grid cells express a rhomboidal grid of high activity spots in any environment, indicating that they are part of a system that integrates velocity and direction of motion to track relative location. McNaughton et al. [2] suggested that grid cell path integration is based on a connectivity matrix originally proposed by Samsonovich and McNaughton [3]. Cells are connected as a function of relative grid phase, forming a torus-shaped continuous attractor. A 'bump' of activity stabilizes by a cooperative interaction among 'neighboring' (in the connectivity sense) cells and can move around the torus in a manner consistent with the rat's motion, causing each cell to reactivate periodically. This motion may be provided by cells observed in MEC layer III that are conjunctive for head direction, linear velocity, and grid location [4].

Grid cells also exhibit theta phase precession, firing at late phases of the theta rhythm when the animal enters a grid node and successively earlier phases as the animal traverses the node [5]. One model for phase precession $[6,7]$ is based on asymmetry in the intrinsic connections, which causes the network to 'look-ahead' of the rat during each theta cycle and then reset at the 'actual' location of the animal at the beginning of the next theta cycle as a result of external input. This model, however, is inadequate to account for omnidirectional phase precession in
2-D environments or for precession during path integration without external cues to reset the activity each cycle.

We propose a more parsimonious system-level model in which the 'look-ahead' is determined by the rate of activity of the conjunctive cells, which drives the bump forward, and the reset is determined by an intrinsic afterdepolarization current whose time constant induces the bump to form slightly ahead of its initial location on the previous cycle. A 1-D version of this model was implemented using the NEURON simulator. The model generates phase precession in both possible directions of travel, with no external reset mechanism. As predicted, changing the time constant of the after-depolarization, in a manner consistent with the observed variation along the dorsoventral axis of MEC [8] changes the grid scale accordingly.

\section{References}

I. Hafting T, Fyhn M, Molden S, Moser MB, Moser El: Microstructure of a spatial map in the entorhinal cortex. Nature 2005, 436:80I-806

2. McNaughton BL, Battaglia FP, Jensen O, Moser EI, Moser MB: Path integration and the neural basis of the 'cognitive map'. Nat Rev Neurosci 2006, 7:663-678.

3. Samsonovich A, McNaughton BL: Path integration and cognitive mapping in a continuous attractor neural network model. J Neurosci 1997, 17:5900-5920.

4. Sargolini F, Fyhn M, Hafting T, McNaughton BL, Witter MP, Moser $M B$, Moser El: Conjunctive representation of position, direction, and velocity in entorhinal cortex. Science 2006, 3 I 2:758-762.

5. Hafting T, Fyhn M, Moser MB, Moser El: Phase precession in entorhinal grid cells. in press.

6. Tsodyks MV, Skaggs WE, Sejnowski TJ, McNaughton BL: Population dynamics and theta rhythm phase precession of hippocam- 
pal place cell firing: a spiking neuron model. Hippocampus 1996, 6:27|-280.

7. Jensen $\mathrm{O}$, Lisman JE: Hippocampal CA3 region predicts memory sequences: accounting for the phase precession of place cells. Learn Mem 1996, 3:279-287.

8. Giocomo LM, Zilli EA, Fransén E, Hasselmo ME: Temporal frequency of subthreshold oscillations scales with entorhinal grid cell field spacing. Science 2007, 315:1719-1722.

Publish with Bio Med Central and every scientist can read your work free of charge

"BioMed Central will be the most significant development for disseminating the results of biomedical research in our lifetime. " Sir Paul Nurse, Cancer Research UK

Your research papers will be:

- available free of charge to the entire biomedical community

- peer reviewed and published immediately upon acceptance

- cited in PubMed and archived on PubMed Central

- yours - you keep the copyright

Submit your manuscript here:

http://www.biomedcentral.com/info/publishing_adv.asp 